\title{
Asthma-COPD overlap szindróma
}

\author{
Odler Balázs dr. - Müller Veronika dr.
}

Semmelweis Egyetem, Általános Orvostudományi Kar, Pulmonológiai Klinika, Budapest

\begin{abstract}
Az obstruktív tüdőbetegségek világszerte jelentős népegészségügyi problémát jelentenek, magas prevalenciájuk és a társadalmat érintő nagy szocioökonómiai költségeik miatt. Az asthma bronchiale és a krónikus obstruktív tüdőbetegség krónikus légúti gyulladással járó betegségek, amelyeket légúti obstrukció jellemez, azonban külön nozológiai entitások, figyelembe véve kialakulásukat, diagnosztikájukat, a terápiás megfontolásokat és prognosztikai jellemzőiket. A két betegség együttesen is előfordulhat, vagy az egyik állapot képes a másik jellemzőit felvéve, abba átalakulni. Ezt a kevert asthma-COPD fenotípust nevezzük asthma-COPD overlap szindrómának, amelyet úgy jellemeznek, hogy olyan perzisztáló légúti áramláskorlátozottsággal járó betegség, amely rendelkezik mind az asthma, mind a krónikus obstruktív tüdőbetegség egyes jellemzőivel. A szindróma az elmúlt években jelentős figyelmet kapott, azonban a betegek nagy része mostanáig kizárásra került a klinikai és légúti gyógyszer-hatásossági vizsgálatokból, így a jól meghatározott klinikai jellemzők és a megfelelő terápia továbbra sem ismertek. Az összefoglaló közlemény elsődleges célja az elmúlt években leírt patofiziológiai és klinikai jellemző́k, terápiás megfontolások és irodalmi újdonságok bemutatása. Orv. Hetil., 2016, 157(33), 1304-1313.
\end{abstract}

Kulcsszavak: ACOS overlap szindróma, COPD, asthma bronchiale, obstruktív, terápia

\section{Asthma-COPD overlap syndrome}

Obstructive lung diseases represent a major health problem worldwide due to their high prevalence associated with elevated socioeconomic costs. Bronchial asthma and chronic obstructive pulmonary disease are chronic obstructive ventilatory disorders with airway inflammation, however they are separate nosological entities based on thedifferent development, diagnostic and therapeutic approaches, and prognostic features. However, these diseases may coexist and can be defined as the coexistence of increased variability of airflow in a patient with incompletely reversible airway obstruction. This phenotype is called asthma - chronic obstructive pulmonary disease overlap syndrome. The syndrome is a clinical and scientific challenge as the majority of these patients have been excluded from the clinical and pharmacological trials, thus well-defined clinical characteristics and therapeutic approaches are lacking. The aim of this review is to summarize the currently available literature focusing on pathophysiological and clinical features, and discuss possible therapeutic approaches of patients with asthma - chronic obstructive pulmonary disease overlap syndrome.

Keywords: ACOS overlap syndrome, COPD, bronchial asthma, obstruction, therapy

Odler, B., Müller, V. [Asthma-COPD overlap syndrome]. Orv. Hetil., 2016, 157(33), 1304-1313.

(Beérkezett: 2016. május 13.; elfogadva: 2016. június 9.)

\begin{abstract}
Rövidítések
$\% \mathrm{CSA}<5=5 \mathrm{~mm}^{2}$-nél kisebb erek átmérőjének százalékos aránya; $\mathrm{AA}=$ afroamerikai; $\mathrm{ACOS}=$ asthma-COPD overlap szind róma; $\mathrm{ACT}=$ asthmakontrollteszt; $\mathrm{BHR}=$ fokozott válaszadó készség; $\mathrm{BMI}=$ testtömegindex; BODE-index = body mass index (testtömegindex), airflow obstruction (légúti obstrukció), dyspnea and exercise capacity (légszomj és terhelési kapacitás); BOLD = Burden of Obstructive Lung Diseases; CAT =
\end{abstract}

COPD Assessment Test; COPD = krónikus obstruktív tüdőbetegség; $\mathrm{CRP}=\mathrm{C}$ reaktív protein; $\mathrm{CT}=$ komputertomográfia; ECLIPSE = Evaluation of COPD Longitudinally to Identify Predictive Surrogate End-points; FeNO = kilégzett nitrogénmonoxid; $\mathrm{FEV}_{1}=1$ másodperc alatti erőltetett kilégzési volumen; GINA = Global Initiative for Asthma; GOLD = Global Initiative for Chronic Obstructive Pulmonary Disease; ICS = inhalációs kortikoszteroid; IgE = immunglobulin E; IL-6 = in- 
terleukin-6; NHW = nem hispán kaukázusi; SEPAR = $($ Spanish Society of Pneumology and Thoracic Surgery) Spanyol Pulmonológiai és Mellkassebészeti Társaság; SNP = egynukleotid-polimorfizmus; SP-A = surfactant protein A; Th-1, 2, 17 = T-helper $1,2,17 ;$ TNF- $\alpha=$ tumornekrózis-faktor- $\alpha$; WA $\%=$ fal területének százalékos aránya

Per definitionem az asthma bronchiale olyan heterogén betegség, amelyet krónikus légúti gyulladás jellemez számos gyulladásos sejt és sejtalkotó részvételével. A gyulladás következtében fokozott légúti hiperreaktivitás (fokozott válaszadó készség - BHR) jön létre a különböző noxákkal szemben. Klinikai tüneteit tekintve gyakran sípolással, mellkasi feszüléssel, nehézlégzéssel, illetve változó intenzitású (gyakorta éjszaka jelentkező) köhögéssel jár együtt. Ezeket a tüneteket rendszerint reverzibilis légúti obstrukció kíséri, amely spontán vagy gyógyszerre részben vagy teljesen oldódik $[1,2]$. A kórkép, becslések alapján, mintegy 300 millió embert érinthet világszerte, prevalenciája az egyes országoktól függően 1-16\% lehet, és megközelítőleg 346000 halálesetért lehet felelős a világon [1].

A krónikus obstruktív tüdőbetegséget (COPD) gyakori, megelőzhető és kezelhető betegségként határozzuk meg, amely perzisztáló, irreverzibilis légúti áramláskorlátozottsággal és a légutak fokozott krónikus gyulladásával jár együtt és kiváltó oka gyakorta valamilyen belélegzett károsító noxa (például dohányfüst) vagy gáz. Jellemzően 40 éves kor felett jelenik meg, férfiakban gyakoribb, krónikus köhögéssel és nyákképződéssel jár együtt, míg az exacerbatiók és a komorbiditások száma egyénenként eltérő lehet [3]. A COPD az egyik vezető halálok világszerte, és folyamatos halálozási növekedés várható a következó években. A betegség okozta valós mortalitás még magasabb lehet, hiszen sok esetben „csak” mellékdiagnózisként tüntetik fel. A betegség prevalenciája magasabb a dohányos és korábbi dohányosok között, azonban ennek pontos meghatározása rendkívül nehéz az eltérő diagnosztikus megközelítési módszerek miatt [4]. A nemdohányzóknál a Burden of Obstructive Lung Diseases (BOLD) tanulmány alapján a betegség megjelenése a különböző országokban 3 és 11\% közé tehető [4].

Annak ellenére, hogy mindkét betegség a légutak krónikus gyulladásával jár együtt és légúti obstrukció jellemzi, külön entitásként kezeljük őket, a patogenezisben, diagnosztikában, illetve a terápiás és prognosztikus jellemzókben látott különbségek alapján [5]. Mégsem fedik le teljes mértékben az obstruktív tüdőbetegségek teljes spektrumát, amelyekkel a klinikai gyakorlatban gyakran találkozni lehet. Példaként említve azokat a dohányos asthmás betegeket, akiknél a légzésfunkció fokozott romlása figyelhető meg [6] vagy azokban az esetekben, amikor a COPD-ben szenvedő betegeknél fennáll allergiás megbetegedés és jelentős légúti reverzibilitás észlelhető [7].
A két betegség gyakoriságánál fogva együttesen is előfordulhat, vagy az egyik állapot képes a másik legfontosabb jellemzőit mutatni és esetenként a másik kórképbe átalakulni. Ezt a kevert, mindkét kórkép jellemzőit mutató asthma-COPD fenotípust nevezzük asthma-COPD overlap szindrómának (ACOS). A kórkép megjelenése meglehetősen széles skálán mozog. COPD-betegek esetében az ACOS megjelenése 10-55\%-ra tehető, attól függően, hogy milyen diagnosztikus kritériumok alapján készült a vizsgálat. Megfigyelhető, hogy az életkor előrehaladtával az ACOS prevalenciája emelkedik [8-10], míg a populáción belüli átlagos megjelenése $2 \%$-ra tehető $[11,12]$. A magas prevalencia ellenére a betegek jelentős része eddig kizárásra került a kontrollált, kettős vak, illetve prospektív klinikai vizsgálatokból és az inhalatív gyógyszerek hatásossági vizsgálataiból. Ennek következtében a hatásos és eredményes terápia e betegek esetében nem ismert. További probléma, hogy jelenleg nincs általánosan elfogadott, elérhető és validált kritériumrendszer az ACOS diagnózisához. 2012-ben került publikálásra a spanyol konszenzusdokumentum az ACOS COPD-ben való szerepéről [13], illetve a 2015ben publikált GINA (Global Initiative for Asthma) és GOLD (Global Initiative for Chronic Obstructive Lung Disease) dokumentumok is már tartalmaznak ajánlásokat ezeknek a betegeknek az azonosításához [14]. További nem elhanyagolható szempont, hogy a betegséghez kapcsolódó egészségügyi kiadások közel kétszer olyan magasak az ACOS-betegek esetében, mint az asthma vagy COPD önálló fennállása esetén $[15,16]$. Az 1. táblázatban foglaltuk össze azokat a kérdéseket, amelyek az ACOS fontosságának aktualitását mutatják meg.

$\mathrm{Az}$ asthma és a COPD közötti különbségtétel diagnosztikai nehézségei már régóta foglalkoztatják a szakmát. 1962-ben Orie és mtsai publikálták az úgynevezett „Holland hipotézis” elméletet, amelyben részletesen foglalkoznak a problémával [17]. Az akkoriban még nem elérhető molekuláris biológiai technikák hiányában is felismerték, hogy az obstruktív tüdőbetegségek (mint az asthma bronchiale és a COPD) genetikai és környezeti faktorok által meghatározott betegségek, amelyeket

1. táblázat | Miért fontos az asthma-COPD overlap szindróma?

1. Magas prevalencia: A különböző tanulmányok alapján az ACOS prevalenciája 10-55\% közé tehetó, továbbá a betegség populációs előfordulása $2 \%$.

2. Magas egészségügyi kiadások: Az ACOS-hoz kapcsolódó egészségügyi költségek magasabbak, mint az önállóan előforduló asthma bronchiale vagy COPD esetén.

3. Súlyosabb klinikai jellemzők: Az ACOS-betegek gyakran súlyosabb klinikai tulajdonságokkal rendelkeznek, mint az asthma bronchialés vagy COPD-betegek.

4. Terápiás indikációk: Az ACOS pontos kezelési irányelvei ma még nem teljesen tisztázottak, sok esetben nem megfelelő terápiát kaphat a beteg.

5. Kutatási potenciál: Jelentős igény a betegség patofiziológiai és klinikai jellemzőinek pontos meghatározására. 
azonban befolyásolhat a nem, és a korral változhatnak [18]. A szerzők szavait felhasználva: a hipotézis áttételesen Williams Worthworth szavaival írható le: „The child is father of the man” - „A gyermek az ember édesapja”, ami átértelmezve úgy fogalmazható meg, hogy 'az asthmás gyermek a COPD-s felnőtt édesapja' [19].

Az ACOS vagy a kevert fenotípus jelentős részét jelentheti az obstruktív tüdőbetegeknek, ezért rendkívül fontos a pontos karakterizálhatóság. Így a fentieket figyelembe véve, közleményünk célja átfogó képet adni az aktuális szakirodalom áttekintésével az ACOS eddig ismert patogeneziséról, klinikai tulajdonságairól, diagnosztikai kihívásairól, terápiás, illetve prognosztikai jellemzőiről. Mindezzel segítséget nyújtva a betegség jobb megismeréséhez és a klinikai gyakorlatban való döntéshozatal elősegítéséhez.

\section{Patogenezis}

\section{Genetika}

Az olyan komplex betegségekben, mint az asthma és a COPD, ahol jelentős szerepe van a gén-gén, illetve génkörnyezet interakcióknak, ott mindenképp felmerül a két betegség komplex patofiziológiai hátterének genetikai vonatkozásbeli átfedése is [20]. Kizárólag az ACOS-t is figyelembe vevő genetikai analízis csupán néhány esetben készült. A COPDGene vizsgálat során több mint 10000 olyan nem hispán kaukázusi (NHW) és afroamerikai (AA) egyénekből álló populációt vizsgáltak, akiknél COPD diagnózisát állították fel, majd azoknak a betegeknek az adatait hasonlították össze a COPD-betegek genetikai adataival, akiknél szakorvosi vélemény alapján 40 éves kor előtt asthma diagnózisát is felállították. Az eredmények alapján az NHW-csoportban a CSMDl és SOX5, továbbá a GPR65 génekben olyan egynukleotidpolimorfizmusokat (SNP) azonosítottak, amelyek új genetikai variánsként jelentek meg a szindrómában [21]. Ennek ellenére a további genomszintű asszociációs vizsgálatoknak még nem sikerült egyértelmű genetikai hátteret azonosítani [22]. Egy kisebb tanulmányban a mitochondrialis DNS (amely rendkívül érzékeny az oxidatív stresszhatásokra, ami az obstruktív tüdőbetegségekben különösen jellemző) változása azonosítható volt ACOSbetegekben, ahol a COPD-hez és az asthmához képest az MtDNA/nDNA arány magasabb volt, ami hasznos marker lehet az ACOS, COPD és asthma elkülönítő kórisméjében [23].

\section{Szisztémás és légúti gyulladás}

A szisztémás gyulladás közvetlen patofiziológiai szerepe kevésbé merül fel az asthma és a COPD esetében, jelenléte inkább a komorbiditásokkal és a betegség súlyosságával függhet össze. Az ACOS esetében keveset tudunk szerepéről, az ezzel kapcsolatban készült vizsgálatok alapján a COPD-hez hasonló szisztémás gyulladásos markerek emelkedése figyelhető meg, többek között az interleukin-6 (IL-6), C reaktív protein (CRP), tumornekrózis-faktor- $\alpha$ (TNF- $\alpha)$ és surfactant protein A (SP-A) emelkedésével [24].

Jól ismert, hogy a légúti gyulladás jellege különbözik asthmában és COPD-ben. Asthmára leggyakrabban eozinofil gyulladás jellemző a T helper 2 (Th2) lymphocyta túlsúlyával [1]. Míg COPD-ben T helper 1 (Thl) és T helper 17 (Th17) sejtek vezérelte, döntően neutrofil gyulladás dominál CD8 lymphocyta túlsúllyal. Jelentős szerepet kapnak a makrofágok is, amely sejtek gyulladásos mediátorokat és enzimeket termelve interakcióba lépnek a légutakat, tüdőparenchymát és vasculaturát felépítő sejtekkel [4]. Ettől függetlenül, az eozinofil sejtek COPD-ben, illetve a neutrofil sejtek asthmában betöltött szerepe is széles körben vizsgált. Azok az asthmás betegek, akiknél súlyosabb és később kezdődő betegség vagy krónikus infekciók, vagy dohányzás igazolható, ott neutrofil gyulladás is megfigyelhetô volt a légutakban $[25,26]$. A köpet neutrofilszáma összefüggést mutatott a súlyosabb asthmafenotípusokkal, amelyek magas dózisú inhalációs vagy orális kortikoszteroidhasználat ellenére is több egészségügyi kezeléssel és csökkent légzésfunkciós értékekkel párosultak [27]. A másik fontos megfigyelés, hogy a COPD-betegek 20-40\%-ánál a köpet eozinfilszintje emelkedett [28], illetve 15-40\%-ban a sejtek jelen voltak a bronchoalveolaris lavage és tüdőszöveti mintákban is [29]. COPD-ben a köpet eozinofilszámának csökkenése összefüggést mutatott az 1 másodperc alatti eróltetett kilégzési volumen $\left(\mathrm{FEV}_{\mathrm{l}}\right)$ enyhe, illetve a betegségspecifikus kérdőívek eredményeinek javulásával bronchodilatator adását követően [30]. Nagyobb esetszámú klinikai vizsgálatok alapján a vér emelkedett eozinofilsejt-száma csökkent exacerbatiós rátával járt együtt hosszú hatású $\beta_{2}$-agonista kezeléshez hozzáadott inhalációs kortikoszteroid- (ICS-) kezeléssel [31]. $\mathrm{Az}$ ECLIPSE (Evaluation of COPD Longitudinally to Identify Predictive Surrogate End-points) tanulmányban a COPD-betegek 37,4\%-ában volt megfigyelhető perzisztáló eozinofília (eozinofilszint $>2 \%$ a vérben) a 3 éves követés során [32, 33]. Azoknál a betegeknél, akiknél eozinofília volt jelen, kevesebb volt az aktív dohányos, némileg magasabb volt az idősebb férfiak aránya, kevesebb tünet, jobb életminőség és magasabb $\mathrm{FEV}_{1}$ volt megfigyelhető [34]. Mindemellett a köpet és a légúti eozinofília jobb ICS-válasszal járt együtt $[35,36]$.

Egy több mint 4000 légúti betegnél a légúti gyulladásos profilt vizsgáló tanulmányban a betegek $9 \%$-ának volt ACOS diagnózisa. Ezen betegek 35\%-ában eozinofilbronchitis, 19\%-ában neutrofilbronchitis és 10\%-ában kevert gyulladásos mintázat volt megfigyelhető [37]. Összességében elmondható, hogy a jelenlegi álláspont és tanulmányok alapján az ACOS-ra heterogén légúti gyulladás lehet jellemző, jelentősebb eozinofil légúti gyulladás jelenlétében $[14,35,38]$. 


\section{Bronchodilatator-reverzibilitás és BHR}

$\mathrm{Az}$ asthma és a COPD diagnosztikájában is kiemelten fontos a reverzibilitási vizsgálat, ahol a légúti obstrukció mértékének, gyors hatású hörgőtágító adását követően $>12 \%$-kal vagy $\geq 200$ ml-rel való $\mathrm{FEV}_{1}$ és vagy forszírozott vitálkapacitás (FVC) javulása a BHR és ezzel párhuzamosan sok esetben az asthma jellegzetes tulajdonságaként ismert [39]. Azoknál az asthmabetegeknél, akiknél a betegségkontroll optimális, általában már a kiindulási légzésfunkciós eredmények is megfelelőek.

Azonban ma már tudjuk, hogy a COPD-betegek több mint 50\%-ában jelen lehet a BHR, továbbá az asthmabetegek egy része nem mutathat reverzibilitást [40]. Számos tanulmány igazolta, hogy a COPD-betegek légúti reverzibilitása időról időre változhat és függ a beteg egyéni jellemzőitől $[8,41]$.

A kiindulási légzésfunkciós értékek esetében megoszlanak az eredmények a különböző tanulmányokban, jelentôs különbséget nem sikerült kimutatni az ACOSbetegek esetében a COPD-csoporthoz képest [42]. A hörgőtágító alkalmazását követő légúti reverzibilitás tekintetében azonban az ACOS-betegek esetében jelentősebb javulás figyelhető meg a COPD-betegekhez képest $[43,44]$. Abban az esetben, ha a légúti reverzibilitás mértéke meghaladja a $\mathrm{FEV}_{1} \geq 15 \%$ és $\geq 400 \mathrm{ml}$ értéket, akkor az ACOS diagnózisa valószínűsíthető $[1,14]$.

A BHR jellemzően jelen van a krónikus légúti betegségekben, azonban az egészséges populációban való megjelenése esetén is nagyobb az esélye, hogy légzőszervi tünetek alakuljanak ki, továbbá rosszabb légzésfunkciós eredményekhez és a tüdőfunkció gyorsabb csökkenéséhez járul hozzá [19]. A BHR általában az asthma jellemzőjeként kerül leírásra, ahol magasabb exacerbatiós rátával és emelkedett légúti eozinofil gyulladással jár együtt $[45,46]$. Azonban független prediktor lehet COPD-ben is, ahol az enyhe COPD-s betegek esetében hosszú távon a tüdőfunkció romlása gyorsabb ütemú, illetve e betegcsoportban magasabb a mortalitás $[19,47$, 48]. A különböző tanulmányok alapján a BHR a COPDbetegek 60-90\%-ában jelen lehet $[49,50]$. Ezért a BHR mind a COPD, mind az asthma kialakulására és súlyosságára is rizikófaktort jelent, azonban további vizsgálatok szükségesek annak feltárására, hogy az ACOS-ban pontosan milyen szerepe van és mennyiben függ össze a betegség súlyosságával.

\section{Epidemiológia és súlyosság}

Az ACOS pontos prevalenciája nem ismert. A bevezetóben említettek szerint az epidemiológiai adatok széles skálán mozognak, így a vizsgálati populációk és bevonási kritériumok alapján a prevalenciaadatok eltérőek lehetnek a COPD-populáción belül [9]. Egyes tanulmányok tükrében a 60 év feletti obstruktív tüdőbetegek több mint 50\%-a, míg a súlyos asthmában szenvedő betegek 25\%-a teljesíti az ACOS kritériumait $[25,51]$. Matsu- moto és kollégái által leírt vizsgálatban a japán populációban magasabb volt az ACOS prevalenciája férfiakban és a dohányosokban [52]. A férfiakban észlelt magasabb elöfordulási arányt más vizsgálatok is megerősítették [53].

\section{Definíció és diagnosztikai megfontolások}

Az irodalomban elérhető adatok alapján számos kritériumrendszert használnak az ACOS definíciójának meghatározásához [54]. A GINA-GOLD dokumentumokban megfogalmazott új definíció alapján az ACOS olyan változó karakterisztikájú légúti áramláskorlátozottsággal jellemzett kórkép, amelynek tulajdonságai általában az asthma és a COPD jellemzőivel párosulnak. Az ACOS azonosítása a klinikai gyakorlatban akkor mondható ki, ha mind a két betegség jellemzői fellelhetőek egy adott betegnél. A dokumentum kitér arra is, hogy a specifikus definícióhoz még további vizsgálatok szükségesek a különféle fenotípusok pontos meghatározásával. A légúti obstrukció igazolása után asthma, $\mathrm{COPD}$, valamint valószínú asthma és valószínű COPD csoportok mellett lehet az ACOS klinikai diagnózisát felállítani [15].

Ennél konkrétabb és részletesebb kritériumokat ad meg a spanyol konszenzusdokumentum az ACOS azonosításához [14], amely alapján az ACOS diagnózisa abban az esetben állítható fel, ha az alábbiak közül két major vagy 1 major és 2 minor kritérium teljesül:

- Major kritériumok: erősen pozitív bronchodilatatorteszt: $\mathrm{FEV}_{1} \geq 15 \%$ és $\geq 400 \mathrm{ml}$; köpeteozinofília; asthma diagnózis az anamnézisben (40 éves kor alatt).

- Minor kritériumok: magas össz-IgE; atópia; pozitív bronchodilatator-teszt: $\mathrm{FEV}_{1} \geq 12 \%$ és $\geq 200 \mathrm{ml}$ ( 2 vagy több alkalommal).

Hasonló szempontok alapján osztályoz a Cseh Pulmonológiai és Fiziológia Társaság konszenzusirányelve is, ahol ugyancsak két major vagy 1 major és 2 minor kritérium teljesülése esetén mondható ki az ACOS diagnózisa:

- Major kritériumok: erősen pozitív bronchodilatatorteszt: $\mathrm{FEV}_{1} \geq 15 \%$ és $\geq 400 \mathrm{ml}$; pozitív bronchoconstrictiós teszt; $\mathrm{FeNO} \geq 45-50 \mathrm{ppb}$ és/vagy köpeteozinofilia $\geq 3 \%$; asthma az anamnézisben.

- Minor kritériumok: pozitív bronchodilatator-teszt: $\mathrm{FEV}_{\mathrm{l}} \geq 12 \%$ és $\geq 200 \mathrm{ml}$; emelkedett össz-IgE; atópia és biztos COPD diagnózis az anamnézisben.

Mind a GINA, GOLD és a SEPAR (Spanish Society of Pneumology and Thoracic Surgery) által kiadott dokumentumok elismerik az ACOS fontosságát és felhívják a figyelmet a további karakterizálás és egy pontos kritériumrendszer megalkotásának fontosságára.

\section{Klinikai jellemzők}

\section{Karakterisztika, rizikófaktorok}

Az eddig elérhető tanulmányok alapján az ACOS-betegek több tünettel, magasabb és súlyosabb exacerbatiós és hospitalizációs rátával rendelkezhetnek $[43,56]$. Ki- 
emelten fontos, hogy az ACOS-betegek rosszabb életminőségi mutatókkal rendelkeznek, mint a COPD- vagy asthmabetegek önmagukban $[57,58]$. Hardin és mtsai eredményei alapján az ACOS-betegekben magasabb BODE (body mass index, airflow obstruction, dyspnea and exercise capacity) és Szent György légzőszervi kérdőív pontszám volt megfigyelhető, amely tünetesebb állapotot igazol [21]. Egy másik tanulmány alapján a COPD-betegek között azonosított COPD-asthma fenotípusú betegeknél rosszabb légúti tünetekhez kötött életminőségi mutatók, jelentősebb nehézlégzés és csökkent fizikai aktivitás volt megfigyelhető [59]. Az ACOSbetegekben, hasonlóan a COPD-hez, D-vitamin-hiány figyelhető meg, amely rizikófaktort jelenthet az ACOSbetegek esetében a rosszabb életminőségre és a betegségkontroll romlására [60]. Kiemelendő, hogy az ACOSbetegek esetében azonban nem rendelkezünk betegségspecifikus kérdőívekkel. Munkacsoportunk eredményei alapján az ACOS-betegek asthmakontrollteszt (ACT) pontszáma jelentôsen alacsonyabb volt az asthmás betegekhez képest, azonban a COPD Assessment Test (CAT) eredményeiben nem volt szignifikáns különbség a COPD-csoporthoz képest [61]. Több tanulmány alapján megfigyelhető, hogy az ACOS-betegek testsúlya és testtömegindexe (BMI) általában magasabb, mint a COPD-betegeké $[8,43,60]$.

A COPD és az asthma esetében is több rizikófaktor ismert, amelyek közül sok egyértelmúen az adott betegségre jellemző. A betegségben eltöltött idő előrehaladtával, a betegség krónikus jellegéből, az öregedésból és a környezeti hatásokból adódóan ezek elkülönítése egyre nehezebbé válik, mégis egyes jellemzők erôsíthetik az egyik vagy a másik obstruktív légúti betegség diagnózisát. Asthmára jellemzően a gyermekkori légúti betegségek, allergiás megbetegedések (rhinitis), magas IgE és kilégzett NO, illetve Th-2 sejt vezérelte légúti gyulladás hajlamosít. COPD-re az idősebb kor (>40 év), a rosszabb szocioökonóniai körülmények (belső tüzelésû hőforrások, rosszabb táplálkozás), dohányzás és egyéb dohánytermékek fogyasztása, légszennyezés, emphysema hajlamosít. Egyes rizikótényezők mindkét kórképre jellemzők, mint a genetikai háttér, az édesanya terhesség alatti dohányzása, illetve a gyermekkori légúti fertőzések. Ezek közül kiemelendő néhány, amely az eddigi tanulmányok alapján inkább az ACOS-csoportra jellemző: feltételezhetően a BHR, kevert típusú légúti gyulladás eozinofilsejttúlsúllyal, gyakori exacerbatiók és infekciók, hiperinfláció és légcsapdák, magasabb BMI. Az elkülönítés azonban nem egyszerü, hiszen a rizikófaktorok sok esetben mindegyik kórképnél előfordulhatnak, így körültekintő mérlegelést igényel elkülönítésük és rendszerezésük.

\section{Komorbiditások és exacerbatiók}

A COPD-re általánosan jellemző a komorbiditások jelenléte, amely jelentősen befolyásolhatja a betegség súlyosságát. Ezzel szemben asthmában kevésbé jelentős a szerepük, ami alól a súlyos, illetve időskori asthma jelent kivételt [61-63]. Egy több mint 5000 ACOS-beteget számláló vizsgálatban, összehasonlítva a COPD-populációval (>22 000 fó), magasabb arányban volt jelen az osteoporosis, szorongás, a refluxbetegség és allergiás rhinitis, míg alacsonyabb volt a krónikus veseelégtelenség és az ischaemiás szívbetegség megjelenése [64]. A cardiovascularis betegségek tekintetében más tanulmány is alacsonyabb arányról számolt be a COPD-vel összehasonlítva, azonban az asthmás csoporthoz képest jelentősebb arányban volt jelen [57]. A pneumonia előfordulása az ACOS-betegeknél gyakoribb és nagyobb exacerbatiós rátával járt együtt, mint a COPD-s betegeknél [65]. Egy másik vizsgálat alapján a leggyakoribb halálok az ACOSbetegeknél malignitás miatt következett be, hasonló arányban, mint az asthmabetegeknél ( $57,4 \%$ vs. $54,5 \%)$. Asthmás betegek esetében a tüdő- és mediastinalis tumorok, míg az ACOS-betegek esetében a gastrointestinalis és urológiai tumorok fordultak elő leggyakrabban [66]. Több tanulmány is foglalkozott a diabetes jelenlétének arányával, és a legtöbb tanulmány eredményei alapján magasabb volt a betegség előfordulása, mind az asthmához, mind a COPD-hez képest, azonban ez a különbség nem volt szignifikáns [57]. Azzal kapcsolatban, hogy a komorbiditások milyen hatással vannak a klinikai kimenetelre, az életminóségre, illetve a mortalitásra, még alig áll adat rendelkezésre, így ez a terület is további kutatásokat igényel.

\section{Radiológiai eltérések}

Kevés tanulmány foglalkozik az ACOS radiológiai sajátosságaival. Suzuki és mtsai 40 ACOS-beteg komputertomográfiás (CT) felvételeit elemezték, és vizsgálták a proximalis légutak vastagságát (WA\% - [percentage of wall area] a fal területének százalékos aránya), illetve a pulmonalis erek változásait és perfúzióját $(\% \mathrm{CSA}<5-$ [cross-sectional area of pulmonary vessels less than 5 $\mathrm{mm}^{2}$ ] $5 \mathrm{~mm}^{2}$-nél kisebb erek átmérőjének százalékos aránya). Eredményeik alapján mind a WA\%, mind a $\% \mathrm{CSA}<5$ értékek szignifikánsan magasabbak voltak, mint a COPD-betegek esetében, amiból arra lehet következtetni, hogy az ACOS egy fóként légúti károsodással jellemezhető fenotípus, illetve a \%CSA $<5$ fontos jellemzője lehet az ACOS-nak [57]. Gelb és mtsai 10 olyan kezelt asthmabeteget vizsgáltak, akik soha nem dohányoztak, és perzisztáló légúti obstrukciójuk volt. Eredményeik alapján a patológiai mintákban az elasztikus rostok nagymértékú csökkenése volt látható, mikroszkópos enyhe centrilobularis emphysema mellett, azonban ezek az elváltozások a CT-felvételeken nehezen voltak azonosíthatók [67]. A COPDGene populáció betegeiben a CT vonatkozásában jelentősebb légcsapdaképződés volt látható az ACOS-betegekben, azonban nem volt különbség a CT-n látható emphysema és a légúti falvastagság tekintetében [68]. Egy további tanulmány CT-denzitometriás eredményei alapján az ACOS-betegekben alacsonyabb 
emphysemaérték és -eloszlás mellett, nagyobb postbronchodilatator légcsapda képződése volt megfigyelhető a COPD-betegekhez képest [69]. Ezekből az eredményekből az látszik, hogy a CT-vizsgálatok hasznos diagnosztikus eszközt jelenthetnek az ACOS azonosításában és a pontosabb klinikai jellemzők meghatározásában.

\section{Terápiás megfontolások}

Az asthma és a COPD terápiájára vonatkozóan jól meghatározott irányelvekkel rendelkezünk. Az ACOS esetében a 2014-ben publikált GINA dokumentum már foglalkozik a betegség kezelésével. Az új megközelítés alapján a krónikus légúti betegségben szenvedő betegnél az asthma vagy a COPD fennállásának valószínüségét kell meghatározni.

Minden obstruktív légúti betegség esetében a gyors hatású hörgőtágítók (gyors hatású $\beta 2$-agonista - SABA és/vagy gyors hatású muszkarinantagonista - SAMA) alkalmazása javasolt.

Abban az esetben, ha a klinikai kép alapján az asthma és COPD között nem lehet egyértelmúen dönteni, akkor kezdetben ICS-kezelés (alacsony vagy közepes dózisban a tüneteknek megfelelően) ajánlott a további vizsgálatok elvégzéséig. Az ICS adagjának beállítása ACOS-ban - csakúgy, mint asthmában - a betegségkont- roll fokához, légzésfunkciós eredményekhez és a köpeteozinofília jelenléte alapján ajánlott [14]. Gyakorta a kezelés a COPD-re jellemző tünetek fennállása esetén hörgtágítókkal kiegészítendő és a kombinált kezelése mindenképp ajánlott. A hosszú hatású muszkarinreceptor-agonisták (LAMA) közül asthmában csupán a tiotropium van törzskönyvezve, így annak használata ajánlható első körben. A hosszú hatású $\beta 2$-receptor-agonista (LABA) és hosszú hatású muszkarinreceptor-agonista (LABA-LAMA) kombinációk esetén nem rendelkezünk klinikai vizsgálatokkal, így alkalmazásuk biztonságossága kérdéses. Hármas terápia alkalmazása esetén jó eredményeket értek el súlyos állapotú COPD-betegek esetén, így alkalmazásuk felmerülhet a súlyos tünetekkel rendelkező ACOS-betegek esetében is [70]. Azonban az asthma jellemzőinek jelenléte esetén nem ajánlott a hörgtágító monoterápia alkalmazása, míg COPD esetében az ICS önálló alkalmazása [1]. Asthma esetében, nem megfelelő kontrollszint esetén, teofillin és leukotriénreceptor-antagonista (LTRA) is alkalmazható. Erre iránymutatás nincs ACOS esetén, de mint részben asthmának megfelelő kórkép, az alkalmazás nem ellenjavallt. Teofillinkészítmények COPD-ben mint alternatív készítmények szintén használhatók. A 2. táblázatban foglaljuk össze a hazánkban szakorvosi támogatással elérhető készítményeket és indikációs köröket az asthma és COPD kezelésére vonatkozóan [71-73].

2. táblázat | Magyarországon szakorvosi támogatással elérhető készítmények és indikációs körök az asthma és COPD kezelésére vonatkozóan

\begin{tabular}{|c|c|c|c|c|c|}
\hline Készítmény & Hatóanyag & Dózis & Napi adagolási mód & $\begin{array}{l}\text { Asthma indikáció } \\
\text { (GINA alapján) }\end{array}$ & $\begin{array}{l}\text { COPD indikáció } \\
\text { (GOLD alapján) }\end{array}$ \\
\hline \multicolumn{6}{|l|}{$\begin{array}{l}\text { Rövid hatású hörgtágítók } \\
\text { (SABA és SAMA) }\end{array}$} \\
\hline Ventolin Evohaler® & Salbutamol & $100 \mu \mathrm{g}$ & $\begin{array}{l}\text { Sz. e. } 200 \mu \mathrm{g} \\
\text { maximum } 6 \times 2 \text { inh. }\end{array}$ & $\begin{array}{l}\text { Igen } \\
\text { (1-5. lépcső) }\end{array}$ & $\begin{array}{l}\text { Igen } \\
(\mathrm{A}, \mathrm{B}, \mathrm{C}, \mathrm{D})\end{array}$ \\
\hline Buventol Easyhaler ${ }^{\circledR}$ & Salbutamol & $200 \mu \mathrm{g}$ & $\begin{array}{l}\text { Sz. e. } 200 \mu \mathrm{g} \\
\text { maximum } 6 \times 1 \\
\text { inhalálva }\end{array}$ & $\begin{array}{l}\text { Igen } \\
\text { (1-5. lépcső) }\end{array}$ & $\begin{array}{l}\text { Igen } \\
(\mathrm{A}, \mathrm{B}, \mathrm{C}, \mathrm{D})\end{array}$ \\
\hline Atrovent $\mathrm{N}^{\circledR}$ & Ipratropium & $21 \mu \mathrm{g}$ & $4 \times 2$ & $\begin{array}{l}\text { Igen } \\
\text { (1-5. lépcső) }\end{array}$ & $\begin{array}{l}\text { Igen } \\
(\mathrm{A}, \mathrm{B}, \mathrm{C}, \mathrm{D})\end{array}$ \\
\hline Berodual ${ }^{\circledR}$ & $\begin{array}{l}\text { Fenoterol és } \\
\text { ipratropium }\end{array}$ & $\begin{array}{l}0,05 / 0,021 \\
\mathrm{mg}\end{array}$ & $\begin{array}{l}\text { Sz. e. } 2 \text { puff, } \\
\text { maximum } 4 \times 2 \\
\text { inhalálva }\end{array}$ & $\begin{array}{l}\text { Igen } \\
(1-5 . \text { lépcső })\end{array}$ & $\begin{array}{l}\text { Igen } \\
(\mathrm{A}, \mathrm{B}, \mathrm{C}, \mathrm{D})\end{array}$ \\
\hline \multicolumn{6}{|l|}{ Hosszú hatású hörgtágítók } \\
\hline \multicolumn{6}{|l|}{ Mono LABA } \\
\hline Atimos $^{\circledR}$ & Formoterol & $12 \mu \mathrm{g}$ & $2 \times 1$ & $\begin{array}{l}\text { Igen } \\
\text { (+ ICS kötelező!) }\end{array}$ & $\begin{array}{l}\text { Igen } \\
(\mathrm{B}, \mathrm{C}, \mathrm{D})\end{array}$ \\
\hline Formoterol Easyhaler $^{\circledR}$ & Formoterol & $12 \mu \mathrm{g}$ & $2 \times 1$ & $\begin{array}{l}\text { Igen } \\
\text { (+ ICS kötelező!) }\end{array}$ & $\begin{array}{l}\text { Igen } \\
(\mathrm{B}, \mathrm{C}, \mathrm{D})\end{array}$ \\
\hline Onbrez Breezhaler® & Indacaterol & 150 és $300 \mu \mathrm{g}$ & $1 \times 1$ & Nincs & $\begin{array}{l}\text { Igen } \\
(\mathrm{B}, \mathrm{C}, \mathrm{D})\end{array}$ \\
\hline $\begin{array}{l}\text { Reviform } \\
\text { Axahaler }^{\circledR}\end{array}$ & Formoterol & $6 \mu g$ & $2 \times 1$ & $\begin{array}{l}\text { Igen } \\
\text { (+ ICS kötelező!) }\end{array}$ & $\begin{array}{l}\text { Igen } \\
(B, C, D)\end{array}$ \\
\hline Serevent Diskus/Evohaler ${ }^{\circledR}$ & Salmeterol & $\begin{array}{l}50 \mu g \text { és } \\
25 \mu \mathrm{g}\end{array}$ & $\begin{array}{l}2 \times 1 \text { és } \\
2 \times 2\end{array}$ & $\begin{array}{l}\text { Igen } \\
\text { (+ ICS kötelező!) }\end{array}$ & $\begin{array}{l}\text { Igen } \\
(\mathrm{B}, \mathrm{C}, \mathrm{D})\end{array}$ \\
\hline
\end{tabular}




\section{2. táblázat folytatása}

\begin{tabular}{|c|c|c|c|c|c|}
\hline Készítmény & Hatóanyag & Dózis & Napi adagolási mód & $\begin{array}{l}\text { Asthma indikáció } \\
\text { (GINA alapján) }\end{array}$ & $\begin{array}{l}\text { COPD indikáció } \\
\text { (GOLD alapján) }\end{array}$ \\
\hline Striverdi Respimat ${ }^{\circledR}$ & Olodaterol & $2,5 \mu \mathrm{g}$ & $1 \times 2$ & Nincs & $\begin{array}{l}\text { Igen } \\
(\mathrm{B}, \mathrm{C}, \mathrm{D})\end{array}$ \\
\hline \multicolumn{6}{|l|}{ Mono LAMA } \\
\hline Bretaris Genuair ${ }^{\circledR}$ & Aclidinium & $322 \mu \mathrm{g}$ & $2 \times 1$ & Nincs & $\begin{array}{l}\text { Igen } \\
(\mathrm{B}, \mathrm{C}, \mathrm{D})\end{array}$ \\
\hline Seebri Breezhaler ${ }^{\circledR}$ & Glicopyrronium & $44 \mu \mathrm{g}$ & $1 \times 1$ & Nincs & $\begin{array}{l}\text { Igen } \\
(\mathrm{B}, \mathrm{C}, \mathrm{D})\end{array}$ \\
\hline Spiriva Handihaler ${ }^{\circledR}$ & Tiotropium & $18 \mu \mathrm{g}$ & $1 \times 1$ & Nincs & $\begin{array}{l}\text { Igen } \\
(\mathrm{B}, \mathrm{C}, \mathrm{D})\end{array}$ \\
\hline Spiriva Respimat ${ }^{\circledR}$ & Tiotropium & $2,5 \mu \mathrm{g}$ & $1 \times 2$ & $\begin{array}{l}\text { Igen } \\
\text { (4-5. lépcső) } \\
\text { Hazánkban nem } \\
\text { támogatott! }\end{array}$ & $\begin{array}{l}\text { Igen } \\
(\mathrm{B}, \mathrm{C}, \mathrm{D})\end{array}$ \\
\hline \multicolumn{6}{|l|}{ LABA-LAMA kombináció } \\
\hline Anoro Ellipta ${ }^{\circledR}$ & $\begin{array}{l}\text { Vilanerol/ } \\
\text { umeclidinium }\end{array}$ & $55 / 22 \mu \mathrm{g}$ & $1 \times 1$ & Nincs & $\begin{array}{l}\text { Igen } \\
(\mathrm{B}, \mathrm{C}, \mathrm{D})\end{array}$ \\
\hline Brimica Genuair $^{\circledR}$ & $\begin{array}{l}\text { Formoterol/ } \\
\text { aclidinium }\end{array}$ & $12 / 340 \mu \mathrm{g}$ & $2 \times 1$ & Nincs & $\begin{array}{l}\text { Igen } \\
(\mathrm{B}, \mathrm{C}, \mathrm{D})\end{array}$ \\
\hline Spiolto Respimat $^{\circledR}$ & $\begin{array}{l}\text { Olodaterol/ } \\
\text { tiotropium }\end{array}$ & $2,5 / 2,5 \mu \mathrm{g}$ & $1 \times 2$ & Nincs & $\begin{array}{l}\text { Igen } \\
(\mathrm{B}, \mathrm{C}, \mathrm{D})\end{array}$ \\
\hline Ultibro Breezhaler $^{\circledR}$ & $\begin{array}{l}\text { Indacaterol/ } \\
\text { glicopyrronium }\end{array}$ & $43 / 85 \mu \mathrm{g}$ & $1 \times 1$ & Nincs & $\begin{array}{l}\text { Igen } \\
(\mathrm{B}, \mathrm{C}, \mathrm{D})\end{array}$ \\
\hline \multicolumn{6}{|l|}{ ICS } \\
\hline \multicolumn{6}{|l|}{ Mono-ICS } \\
\hline Aerox/Aerox Jet ${ }^{\circledR}$ & Budesonide & $200 \mu \mathrm{g}$ & $1 \times 1-4$ & $\begin{array}{l}\text { Igen } \\
(2-5 . \text { lépcső })\end{array}$ & Nincs \\
\hline Alvesco $^{\circledR}$ & Ciclesonide & $160 \mu \mathrm{g}$ & $1 \times 1-4$ & $\begin{array}{l}\text { Igen } \\
\text { (2-5. lépcső) }\end{array}$ & Nincs \\
\hline Budesonid Easyhaler $^{\circledR}$ & Budesonide & 100,200 és $400 \mu \mathrm{g}$ & $\begin{array}{l}2 \times \text { maximum } 1600 \\
\mu^{\& \&}\end{array}$ & $\begin{array}{l}\text { Igen } \\
\text { (2-5. lépcső) }\end{array}$ & Nincs \\
\hline Flixotide Diskus $^{\circledR}$ & Fluticasone & 100,250 és $500 \mu \mathrm{g}$ & $\begin{array}{l}2 \times \text { maximum } 1000 \\
\mu g^{\&}\end{array}$ & $\begin{array}{l}\text { Igen } \\
(2-5 . \text { lépcső })\end{array}$ & Nincs \\
\hline Flixotide Evohaler ${ }^{\circledR}$ & Fluticasone & 125 és $250 \mu g$ & $\begin{array}{l}2 \times \text { maximum } 1000 \\
\mu g^{\&}\end{array}$ & $\begin{array}{l}\text { Igen } \\
(2-5 . \text { lépcső })\end{array}$ & Nincs \\
\hline Fluticazon CIPLA ${ }^{\circledR}$ & Fluticasone & $250 \mu \mathrm{g}$ & $\begin{array}{l}2 \times \text { maximum } 1000 \\
\mu g^{\&}\end{array}$ & $\begin{array}{l}\text { Igen } \\
(2-5 . \text { lépcső })\end{array}$ & Nincs \\
\hline Miflonide $^{\circledR}$ & Budesonide & 200 és $400 \mu \mathrm{g}$ & $2 \times 1-4$ és $2 \times 1-2$ & $\begin{array}{l}\text { Igen } \\
(2-5 . \text { lépcső })\end{array}$ & Nincs \\
\hline Pulmicort Turbuhaler ${ }^{\circledR}$ & Budesonide & $100 \mu \mathrm{g}$ & $\begin{array}{l}2-4 \times \text { maximum } 1600 \\
\mu g^{\&}\end{array}$ & $\begin{array}{l}\text { Igen } \\
(2-5 . \text { lépcső })\end{array}$ & Nincs \\
\hline Reviflut Axahaler ${ }^{\circledR}$ & Fluticasone & 125 és $250 \mu \mathrm{g}$ & $1 \times 1-4$ & $\begin{array}{l}\text { Igen } \\
(2-5 . \text { lépcső })\end{array}$ & Nincs \\
\hline \multicolumn{6}{|l|}{ ICS-LABA kombináció } \\
\hline Airflusol $^{\circledR}$ & $\begin{array}{l}\text { Salmaterol és } \\
\text { fluticasone }\end{array}$ & $\begin{array}{l}50 / 250 \\
\text { és } 50 / 500 \mu \mathrm{g}\end{array}$ & $2 \times 1$ & $\begin{array}{l}\text { Igen } \\
\text { (3-5. lépcső) }\end{array}$ & $\begin{array}{l}\text { Igen } \\
(\mathrm{C}, \mathrm{D})\end{array}$ \\
\hline Bufomix $^{\circledR}$ & $\begin{array}{l}\text { Formoterol és } \\
\text { budesonide }\end{array}$ & $\begin{array}{l}4,5 / 160 \\
\text { és } 9 / 320 \mu \mathrm{g}\end{array}$ & $2 \times 1$ & $\begin{array}{l}\text { Igen } \\
\text { (3-5. lépcső) }\end{array}$ & $\begin{array}{l}\text { Igen } \\
(\mathrm{C}, \mathrm{D})\end{array}$ \\
\hline Dimenio $^{\circledR}$ & $\begin{array}{l}\text { Salmaterol és } \\
\text { fluticasone }\end{array}$ & $\begin{array}{l}50 / 250 \\
\text { és } 50 / 500 \mu \mathrm{g}\end{array}$ & $2 \times 1$ & $\begin{array}{l}\text { Igen } \\
\text { (3-5. lépcső) }\end{array}$ & $\begin{array}{l}\text { Igen } \\
(\mathrm{C}, \mathrm{D})\end{array}$ \\
\hline Foster $^{\circledR}$ & $\begin{array}{l}\text { Beclomethasone } \\
\text { és formoterol }\end{array}$ & $6 / 100 \mu \mathrm{g}$ & Egyéni & $\begin{array}{l}\text { Igen } \\
\text { (3-5. lépcső) }\end{array}$ & $\begin{array}{l}\text { Igen } \\
(\mathrm{C}, \mathrm{D})\end{array}$ \\
\hline
\end{tabular}


2. táblázat folytatása

\begin{tabular}{|c|c|c|c|c|c|}
\hline Készítmény & Hatóanyag & Dózis & Napi adagolási mód & $\begin{array}{l}\text { Asthma indikáció } \\
\text { (GINA alapján) }\end{array}$ & $\begin{array}{l}\text { COPD indikáció } \\
\text { (GOLD alapján) }\end{array}$ \\
\hline Foster Nexthaler® & $\begin{array}{l}\text { Beclomethasone } \\
\text { és formoterol }\end{array}$ & $6 / 100 \mu \mathrm{g}$ & $2 \times 1-2$ & $\begin{array}{l}\text { Igen } \\
(3-5 . \text { lépcső })\end{array}$ & $\begin{array}{l}\text { Igen } \\
(\mathrm{C}, \mathrm{D}) \\
\text { Hazánkban nem } \\
\text { támogatott! }\end{array}$ \\
\hline Relvar Ellipta® & $\begin{array}{l}\text { Fluticasone és } \\
\text { vilanterol }\end{array}$ & $92 / 22 \mu \mathrm{g}$ & $1 \times 1$ & $\begin{array}{l}\text { Igen } \\
\text { (3. és 4. lépcső) }\end{array}$ & $\begin{array}{l}\text { Igen } \\
(\mathrm{C}, \mathrm{D})\end{array}$ \\
\hline Relvar Ellipta ${ }^{\circledR}$ & $\begin{array}{l}\text { Fluticasone és } \\
\text { vilanterol }\end{array}$ & $180 / 22 \mu \mathrm{g}$ & $1 \times 1$ & $\begin{array}{l}\text { Igen } \\
\text { (3. és } 4 \text {. lépcső) }\end{array}$ & Nincs \\
\hline Seretide Discus ${ }^{\circledR}$ & $\begin{array}{l}\text { Salmaterol és } \\
\text { fluticasone }\end{array}$ & $\begin{array}{l}50 / 100,250 \text { és } \\
500 \mu \mathrm{g}\end{array}$ & $2 \times 1$ & $\begin{array}{l}\text { Igen } \\
(3-4 \text {. lépcső })\end{array}$ & $\begin{array}{l}50 / 500 \mu \mathrm{g} \text { igen } \\
(\mathrm{C}, \mathrm{D})\end{array}$ \\
\hline Seretide Evohaler ${ }^{\circledR}$ & $\begin{array}{l}\text { Salmaterol és } \\
\text { fluticasone }\end{array}$ & $\begin{array}{l}25 / 50,125 \text { és } 250 \\
\mu g\end{array}$ & $2 \times 2$ & $\begin{array}{l}\text { Igen } \\
(3-5 \text {. lépcső })\end{array}$ & Nincs \\
\hline $\begin{array}{l}\text { Symbicort Mite/Turbuhaler/ } \\
\text { Forte }^{\circledR}\end{array}$ & $\begin{array}{l}\text { Formoterol és } \\
\text { budesonide }\end{array}$ & $\begin{array}{l}4,5 / 80 ; 4,5 / 160 \\
\text { és } 9 / 320 \mu \mathrm{g}\end{array}$ & $2 \times 1$ & $\begin{array}{l}\text { Igen } \\
(3-5 \text {. lépcső })\end{array}$ & $\begin{array}{l}\text { Turbuhaler és } \\
\text { Forte } \\
\text { igen }(C, D)\end{array}$ \\
\hline Thoreus Discus $^{\circledR}$ & $\begin{array}{l}\text { Salmaterol és } \\
\text { fluticasone }\end{array}$ & $\begin{array}{l}50 / 100,250 \text { és } \\
500 \mu \mathrm{g}\end{array}$ & $2 \times 1$ & $\begin{array}{l}\text { Igen } \\
(3-5 \text {. lépcsó })\end{array}$ & $\begin{array}{l}50 / 500 \mu \mathrm{g} \text { igen } \\
(\mathrm{C}, \mathrm{D})\end{array}$ \\
\hline \multicolumn{6}{|l|}{ Teofillin\# } \\
\hline Egifilin $^{\circledR}$ & Theophyllin & $\begin{array}{l}50 / 200 / 300 \\
\mathrm{mg}\end{array}$ & Egyéni & $\begin{array}{l}\text { Igen } \\
(3-5 . \text { lépcső })\end{array}$ & $\begin{array}{l}\text { Igen } \\
(\mathrm{B}, \mathrm{C}, \mathrm{D})\end{array}$ \\
\hline Euphylong $^{\circledR}$ & Theophyllin & $100 / 250 / 37 \mathrm{mg}$ & Egyéni & $\begin{array}{l}\text { Igen } \\
(3-5 \text {. lépcső })\end{array}$ & $\begin{array}{l}\text { Igen } \\
(\mathrm{B}, \mathrm{C}, \mathrm{D})\end{array}$ \\
\hline Retafyllin $^{\circledR}$ & Theophyllin & $200 / 300 \mathrm{mg}$ & Egyéni & $\begin{array}{l}\text { Igen } \\
(3-5 \text {. lépcső })\end{array}$ & $\begin{array}{l}\text { Igen } \\
(\mathrm{B}, \mathrm{C}, \mathrm{D})\end{array}$ \\
\hline Theopthard $^{\circledR}$ & Theophyllin & $150 \mathrm{mg}$ & Egyéni & $\begin{array}{l}\text { Igen } \\
(3-5 \text {. lépcső })\end{array}$ & $\begin{array}{l}\text { Igen } \\
(\mathrm{B}, \mathrm{C}, \mathrm{D})\end{array}$ \\
\hline Theospirex $^{\circledR}$ & Theophyllin & $\begin{array}{l}150 / 300 \mathrm{mg} \text { és } \\
200 \mathrm{mg} / 10 \mathrm{ml}\end{array}$ & Egyéni & $\begin{array}{l}\text { Igen } \\
(3-5 . \text { lépcső })\end{array}$ & $\begin{array}{l}\text { Igen } \\
(\mathrm{B}, \mathrm{C}, \mathrm{D})\end{array}$ \\
\hline \multicolumn{6}{|l|}{ LTRA\#@ } \\
\hline Eonic $^{\circledR}$ & Montelukast & $10 \mathrm{mg}$ & $1 \times 1$ & $\begin{array}{l}\text { Igen } \\
(2-5 . \text { lépcső })\end{array}$ & Nem \\
\hline Monalux $^{\circledR}$ & Montelukast & $10 \mathrm{mg}$ & $1 \times 1$ & $\begin{array}{l}\text { Igen } \\
(2-5 \text {. lépcső })\end{array}$ & Nem \\
\hline Mondeo $^{\circledR}$ & Montelukast & $10 \mathrm{mg}$ & $1 \times 1$ & $\begin{array}{l}\text { Igen } \\
(2-5 \text {. lépcső })\end{array}$ & Nem \\
\hline $\begin{array}{l}\text { Montelukast }{ }^{\circledR} \text { ORON/STADA/ } \\
\text { TEVA }\end{array}$ & Montelukast & $10 \mathrm{mg}$ & $1 \times 1$ & $\begin{array}{l}\text { Igen } \\
(2-5 . \text { lépcső })\end{array}$ & Nem \\
\hline Singulair ${ }^{\circledR}$ & Montelukast & $10 \mathrm{mg}$ & $1 \times 1$ & $\begin{array}{l}\text { Igen } \\
(2-5 \text {. lépcső })\end{array}$ & Nem \\
\hline
\end{tabular}

Valamennyi készítmény esetében szükséges a gyógyszerek alkalmazási előiratának és a hazai finanszírozási protokollnak a betartása! ICS-LABA kombinációk általában $\mathrm{FEV}_{1}<50 \%$ alatt és gyakori exacerbatio esetén alkalmazhatók COPD-ben.

\#A teljesség igénye nélküli felsorolás, véletlenszerúen kerültek kiválasztásra a leggyakrabban alkalmazott készítmények.

@LTRA esetén filmtabletta formákat tüntettünk fel.

\&Az adott készítmény maximális dózisa naponta, a napi alkalmazási számmal feltüntetve.

Inhalációs eszközök esetén azonos hatóanyag esetén sem helyettesíthetők egymással a készítmények.

\section{Következtetések}

Az ACOS önálló fenotípusként való meghatározása feltétlenül indokolt. Aktuálisan nincs egységes diagnosztikai kritériumrendszer a betegek pontos azonosítására, a tünetek értékelésére és a terápia meghatározására. Klinikai szempontból rendkívül körültekintő fenotipizálásra van szükség a legmegfelelőbb terápia kiválasztásához, amelyben a fentebb összefoglalt rizikófaktorok és klinikai jellemzők segítséget nyújthatnak. A gyakorta roszszabb klinikai kimenetel miatt rendkívül fontos, hogy klinikai vizsgálatokban igazolhassuk ezekben a betegekben a legeredményesebb kezelést. 
Anyagi támogatás: A közlemény megírása anyagi támogatásban nem részesült.

Szerzôi munkamegosztás: A szerzők egyenlő arányban vettek részt a kézirat előkészítésében, az irodalomkutatásban, a megírásban és a végleges kézirat ellenőrzésében. A cikk végleges változatát mindkét szerző elolvasta és jóváhagyta.

\section{Érdekeltségek: A szerzőknek nincsenek érdekeltségeik.}

\section{Irodalom}

[1] Global Strategy for Asthma Management and Prevention (GINA) 2015. http://www.ginaasthma.org

[2] Magyar, P., Losonczy, G.: Bronchial asthma. In: Magyar, P., Losonczy, G. (eds.): Handbook of pulmonology. [Asthma bronciale. In: Magyar, P., Losonczy, Gy. (szerk.): A pulmonológia kézikönyve.] Medicina Könyvkiadó, Budapest, 2012. [Hungarian]

[3] Global Initiative for Chronic Obstructive Lung Disease (GOLD) 2016. http://www.goldcopd.com

[4] Buist, A. S., McBurnie, M. A., Vollmer, W. M., et al.: International variation in the prevalence of COPD (the BOLD Study): a population-based prevalence study. Lancet, 2007, 370(9589), 741-750.

[5] Fabbri, L. M., Romagnoli, M., Corbetta, L., et al.: Differences in airway inflammation in patients with fixed airflow obstruction due to asthma or chronic obstructive pulmonary disease. Am. J. Respir. Crit. Care Med., 2003, 167(3), 418-424.

[6] Lange, P., Parner, J., Vestbo, J., et al.: A 15 year follow-up study of ventilatory function in adults with asthma. N. Engl. J. Med., 1998, 339(17), 1194-2000.

[7] Müller, V., Gálffy, G., Orosz, M., et al.: Characteristics of reversible and nonreversible COPD and asthma and COPD overlap syndrome patients: an analysis of salbutamol Easyhaler data. Int J. Chron. Obstruct. Pulmon. Dis., 2016, 11(1), 93-101.

[8] Miravitlles, M., Alcázar, B., Alvarez, F. J., et al.: What pulmonologist think about the asthma-COPD overlap syndrome. Int. J. Chron. Obstruct. Pulmon. Dis., 2015, 10(1), 1321-1330.

[9] Gibson, P. G., Simpson, J. L.: The overlap syndrome of asthma and COPD: what are its features and how important is it? Thorax, $2009,64(8), 728-735$.

[10] De Marco, R., Pesce, G., Marcon, A., et al.: The coexistence of asthma and chronic obstructive pulmonary disease (COPD): prevalence and risk factors in young, middle-aged and elderly people from the general population. PLoS ONE, 2013, 8(5), e62985.

[11] Pleasants, R. A., Ohar, J. A., Croft, J. B., et al.: Chronic obstructive pulmonary disease and asthma-patient characteristics and health impairment. COPD, 2014, 11(3), 256-266.

[12] Diaz-Guzman, E., Khosravi, M., Mannino, D. M.: Asthma, chronic obstructive pulmonary disease, and mortality in the U.S. population. COPD, 2011, 8(6), 400-407.

[13] Soler-Cataluna, J. J., Cosío, B., Izquierdo, J. L., et al.: Consensus document on the overlap phenotype COPD-asthma in COPD. Arch. Broncopneumol., 2012, 48(9), 331-337.

[14] Global Initiative for Asthma (GINA), Global Initiative for Chronic Obstructive Lung Disease (GOLD). Asthma, COPD, and asthma-COPD overlap syndrome. 2014. http://www.goldcopd.org/asthma-copd-overlap.html

[15] Gerhardsson de Verdier, M., Andersson, M., Kern, D. M., et al.: Asthma and chronic obstructive pulmonary disease overlap syndrome: doubled costs compared with patients with asthma alone. Value Health, 2015, 18(6), 759-766.

[16] Rhee, C. K., Yoon, H. K., Yoo, K. H., et al.: Medical utilization and cost in patients with overlap syndrome of chronic obstruc- tive pulmonary disease and asthma. COPD, 2014, 11(2), 163170.

[17] Orie, N. G., Sluiter, H. J. (eds.): Bronchitis: an international symposium. Royal van Gorcum, Assen, Netherlands, 1962.

[18] Postma, D. S., Weiss, S. T., van den Bergee, M., et al.: Revisiting the Dutch hypothesis. J. Allergy Clin. Immunol., 2015, 136(3), 521-529.

[19] Orie, N. G.: The Dutch Hypothesis. Chest, 2000, 117(5 Suppl. 1), 299S.

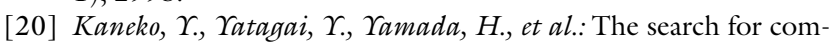
mon pathways underlying asthma and COPD. Int. J. Chron. Obstruct. Pulmon. Dis., 2013, 8, 65-78.

[21] Hardin, M., Cho, M., McDonald, M. L., et al.: The clinical and genetic features of the COPD-asthma overlap syndrome. Eur. Respir. J., 2014, 44(2), 341-350.

[22] Smolonska, J., Koppelman, G. H., Wijmenga, C., et al.: Common genes underlying asthma and COPD? Genome-wide analysis on the Dutch hypothesis. Eur. Respir. J., 2014, 44(4), 860-872.

[23] Carpagnano, G. E., Lacedonia, D., Malerba, M., et al.: Analysis of mitochondrial DNA alteration in new phenotype ACOS. BMC Pulm. Med., 2016, 16(1), 31.

[24] Gibson, P. G., McDonald, V. M.: Asthma-COPD overlap 2015: now we are six. Thorax, 2015, 70(7), 683-691.

[25] Manad, T., Dolbnikoff, M.: Pathologic similiraties and differences between asthma and chronic obstructive pulmonary disease. Curr. Opin. Pulm. Med., 2008, 14(1), 31-38.

[26] Ravensberg, A. J., Slats, A. M., van Wetering, S., et al.: CD8(+) T cells characterize early smoking-related airway pathology in patients with asthma. Respir. Med., 2013, 107(7), 959-966.

[27] Moore, W. C., Hastie, A. T., Li, X., et al.: Sputum neutrophil counts are associated with more severe asthma phenotypes using cluster analysis. J. Allergy Clin. Immunol., 2014, 133(6), 15571563.e5.

[28] Saha, S., Brightling, C. E.: Eosinophilic airway inflammation in COPD. Int. J. Chron. Obstruct. Pulmon. Dis., 2006, l(1), 3947.

[29] Barker, B. L., Brightling, C. E.: Phenotyping the heterogenity of chronic obstructive pulmonary disease. Clin. Sci. (Lond.), 2013, 124(6), 371-387.

[30] Brightling, C. E., Monteiro, W., Ward, R., et al.: Sputum eosinophilia and short-term response to prednisolone in chronic obstructive pulmonary disease: a randomised controlled trial. Lancet, 2000, 356(9240), 1480-1485.

[31] Pascoe, S., Locantore, N., Dransfield, M. T., et al.: Blood eosinophil counts, exacerbations, and response to the addition of inhaled fluticasone furoate to vilanterol in patients with chronic obstructive pulmonary disease: a secondary analysis of data from two parallel randomised controlled trials. Lancet Respir. Med., $2015,3(6), 435-442$.

[32] Singh, D., Kolsum, U., Brightling, C. E., et al.: Eosinophilic inflammation is COPD: prevalence and clinical characteristics. Eur. Respir. J., 2014, 44(6), 1697-1700.

[33] Vestbo, J., Anderson, W., Coxson, H. O., et al.: Evaluation of COPD Longitudinally to Identify Predictive Surrogate Endpoints (ECLIPSE). Eur. Respir. J., 2008, 31(4), 869-873.

[34] Postma, D. S., Rabe, K. F.: The asthma-COPD overlap syndrome. N. Engl. J. Med., 2015, 373(13), 1241-1249.

[35] Postma, D. S., Reddel, H. K., ten Hacken, N. H., et al.: Asthma and chronic obstructive pulmonary disease: similarities and differences. Clin. Chest Med., 2014, 35(1), 143-156.

[36] Papi, A., Romagnoli, M., Baraldo, S., et al.: Partial reversibility of airflow limitation and increased exhaled NO and sputum eosinophilia in chronic obstructive pulmonary disease. Am. J. Respir. Crit. Care Med., 2000, 162(5), 1773-1777.

[37] D'Silva, L., Hassan, N., Wang, H. Y., et al.: Heterogeneity of bronchitis in airway diseases in tertiary care clinical practice. Can. Respir. J., 2011, 18(3), 144-148.

[38] Van den Berge, M., Aalbers, R.: The asthma-COPD overlap syndrome: how is it defined and what are its clinical implications? J. Asthma Allergy, 2016, 9, 27-35. 
[39] American Thoracic Society: Standardization of spirometry. 1994 update. Am. J. Resp. Crit. Care Med., 1995, 152(3), 11071136. Standardization of spirometry. 1994 update.

[40] Tashkin, D. P., Celli, B., Decramer, M., et al.: Bronchodilator responsiveness in patients with COPD. Eur. Respir. J., 2008, $31(4), 742-750$.

[41] Calverley, P. M., Albert, P., Walker, P. P.: Bronchodilator reversibility in chronic obstructive pulmonary disease: use and limitations. Lancet Respir. Med., 2013, 1(7), 564-573.

[42] Alshabanat, A., Zafari, Z., Albanyan, O., et al.: Asthma and COPD overlap syndrome (ACOS): A systematic review and meta analysis. PLOS ONE, 2015,10(9), e0136065.

[43] Menezes, A. M., Montes de Oca, M., Pérez-Padilla, R., et al.: Increased risk of exacerbation and hospitalization in subjects with an overlap phenotype: COPD-asthma. Chest, 2014, 145(2), 297-304.

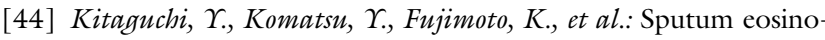
philia can predict responsiveness to inhaled corticosteroid treatment in patients with overlap syndrome of COPD and asthma. Int. J. Chron. Obstruct. Pulmon. Dis., 2012, 7, 283-289.

[45] O'Byrne, P. M., Postma, D. S.: The many faces of airway inflammation. Asthma and chronic obstructive pulmonary disease. Am. J. Respir. Crit. Care Med., 1999, 159(Suppl. 2), S41-S63.

[46] Van den Berge, M., Kerstjens, H. A., Meijer, R. J., et al.: Corticosteroid-induced improvement in the PC20 of adenosine monophosphate is more closely associated with reduction in airway inflammation than improvement in the PC20 of methacholine. Am. J. Respir. Crit. Care Med., 2001, 164(7), 1127-1132.

[47] Rijcken, B., Schouten, J. P., Weiss, S. T., et al.: The relationship of nonspecific bronchial responsiveness to respiratory symptoms in a random population sample. Am. Rev. Respir. Dis., 1987, 136(1), 62-68.

[48] Tashkin, D. P., Altose, M. D., Connett, J. E., et al.: Methacholine reactivity predicts changes in lung function over time in smokers with early chronic obstructive pulmonary disease. The Lung Health Study Research Group. Am. J. Respir. Crit. Care Med., 1996, 153(6), 1802-1811.

[49] Tashkin, D. P., Altose, M. D., Bleecker, E. R., et al.: The Lung Health Study: airway responsiveness to inhaled methacholine in smokers with mild to moderate airflow limitation. Am. Rev. Respir. Dis., 1992, 145(2 Pt 1), 301-310.

[50] Lapperre, T. S., Snoeck-Stroband, J. B., Gosman, M. M., et al.: Effect of fluticasone with and without salmeterol on pulmonary outcomes in chronic obstructive pulmonary disease: a randomized trial. Ann. Intern. Med., 2009, 151(8), 517-527.

[51] Louie, S., Zeki, A. A., Schivo, M., et al.: The asthma-chronic obstructive pulmonary disease overlap syndrome: pharmacotherapeutic considerations. Expert Rev. Clin. Pharmacol., 2013, 6(2), 197-219.

[52] Matsumoto, K., Seki, N., Fukuyama, S., et al.: Prevalence of asthma with airflow limitation, COPD, and COPD with variable airflow limitation in older subjects in a general Japanese population: the Hisayama study. Respir. Investig., 2015, 53(1), 22-29.

[53] Cosio, B. G., Soriano, J. B., López-Campos, J. L., et al.: Defining the asthma-COPD overlap syndrome in a COPD cohort. Chest, 2016, 149(1), 45-52.

[54] Bujarski, S., Parulekar, A. D., Sharafkhaneh, A., et al.: The asthma COPD overlap syndrome (ACOS). Curr. Allergy Asthma Rep., 2015, 15(3), 1-9.

[55] Koblizek, V., Chlumsky, J., Zindr, V., et al.: Chronic obstructive pulmonary disease: official diagnosis and treatment guidelines of the Czech Pneumological and Physiological Society; a novel phenotypic approach to COPD with patient-oriented care. Biomed. Pap. Med. Fac. Univ. Palacky Olomouc Czech Repub., 2013, 157(2), 189-201.

[56] Nielsen, M., Barnes, C. B., Ulrik, C. S.: Clinical characteristics of the asthma-COPD overlap syndrome - a systematic review. Int. J. Chron. Obstruct. Pulmon. Dis., 2015, 10(1), 1443-1454.

[57] Suzuki, T., Tada, Y., Kawata, N., et al.: Clinical, physiological, and radiological features of asthma-chronic obstructive pulmo- nary disease overlap syndrome. Int. J. Chron. Obstruct. Pulmon. Dis., 2015, 10, 947-954.

[58] Knauppi, P., Kupiainen, H., Lindqvist, A., et al.: Overlap syndrome of asthma and COPD predicts low quality of life. J. Asthma, 2011, 48(3) 279-285.

[59] Miravitlles, M., Soriano, J. B., Ancochea, J., et al.: Characterisation of the overlap COPD-asthma phenotype. Focus on physical activity and health status. Respir. Med., 2013, 107(7), 10531060.

[60] Odler, B., Ivancsó, I., Somogyi, V., et al.: Vitamin D deficiency is associated with impaired disease control in asthma-COPD overlap syndrome patients. Int. J. Chron. Obstr. Pulmon. Dis., 2015, 10, 2017-2025.

[61] McDonald, V. M., Higgins, I., Gibson, P. G.: Managing older patients with coexistent asthma and chronic obstructive pulmonary disease: diagnostic and therapeutic challenges. Drugs Aging, 2013, 30(1), 1-17.

[62] McDonald, V. M., Gibson, G. B.: Exacerbations of severe asthma. Clin. Exp. Allergy, 2012, 42(5), 670-677.

[63] Gibson, P. G., McDonald, V. M., Marks, G. B.: Asthma in the older adult. Lancet, 2010, 376(9743), 803-813.

[64] Van Boven, J. F., Román-Rodriguez, M., Palmer, J. F., et al.: Comorbidome, pattern and impact of asthma-COPD overlap syndrome (ACOS) in real life. Chest, 2016, 149(4), 1011-1020.

[65] Chung, W. S., Lin, C. L., Kao, C. H.: Comparison of acute respiratory events between asthma-COPD overlap syndrome and COPD patients. Medicine (Baltimore), 2015, 94(17), e755.

[66] Harada, T., Yamasaki, A., Fukushima, T., et al.: Causes of death in patients with asthma and asthma-chronic obstructive pulmonary disease overlap syndrome. Int. J. Chron. Obstruct. Pulmon. Dis., 2015, 10, 595-602.

[67] Gelb, A. F., Yamamoto, A., Verbeken, E. K., et al.: Unraveling the pathophysiology of the asthma-COPD overlap syndrome: unsuspected mild centrilobular emphysema is responsible for loss of lung elastic recoil in never smokers with asthma with persistent expiratory airflow limitation. Chest, 2015, 148(2), 313-320.

[68] Hardin, M., Silverman, E. K., Barr, R. G., et al.: The clinical features of the overlap between COPD and asthma. Respir. Res., 2011, 12(1), 127.

[69] Gao, r., Zhai, X., Li, K., et al.: Asthma COPD overlap syndrome on CT densitometry: A distinct phenotype from COPD. COPD, 2016. Jan 8. [Epub ahead of print]

[70] Welte, T., Miravitlles, M., Hernandez, P., et al.: Efficacy and tolerability of budesonide/formoterol added to tiotropium in patients with chronic obstructive pulmonary disease. Am. J. Respir. Crit. Care Med., 2009, 180(8), 741-750.

[71] Müller, V., Tamási, L., Somfay, A., et al.: Differences of various inhaler devices with same active compounds for the treatment of obstructive lung diseases. [Az eltérő inhalációs eszközből adagolt azonos hatóanyagú készítmények közötti különbségek.] Med. Thor., 2012, 65(5), 329-335. [Hungarian]

[72] National Health Insurance Fund: The list of the prescipton authorized persons for accentuated indication linked medications. [Országos Egészségbiztositási Pénztár: Az emelt, kiemelt indikációhoz kötött támogatási kategóriába tartozó gyógyszerek, indikációs területek és a felírásra jogosultak köre.] http://www. oep.hu//data/cms1011838/EU_tamogatasi_lista__2016_ 05_01_.pdf [Hungarian]

[73] National Health Insurance Fund: Financing protocol. [Országos Egészségbiztositási Pénztár: Finanszírozási protokoll.] http:// www.kozlonyok.hu/nkonline/MKPDF/hiteles/MK15210.pdf [Hungarian]

(Odler Balázs dr., Budapest, Diós árok 1/C, 1125 e-mail: odler.balazs@med.semmelweis-univ.hu) 